\title{
Клінічний випадок складності діагностики та хірургічного лікування дивертикулу Меккеля
}

У статті наведено випадок складності діагностики дивертикулу Меккеля, ускладненого некрозом та перфорацією дивертикулу, міжпетельним абсцесом, тонкокишковою декомпенсованою непрохідністю, загальним серозним перитонітом.

Ключові слова: дивертикул Меккеля; гострий панкреатит; діагностика; лікування.

Дивертикул Меккеля (ДМ) (J. Meckel, 1809p.) - локальне пальцеподібне випинання стінки клубової кишки (КК), що утворюється внаслідок неповної облітерації жовткової протоки, яка бере участь в живленні ембріону [1].

ДМ знаходиться у дистальному відділі КК на відстані до 200 см від ілеоцекального кута. Здебільшого він знаходиться на відстані 40-50 см від Баугінієвої заслінки. Довжина ДМ становить від 2 до 8 см. У ДМ виділяють верхівку, тіло та шийку. Діаметр шийки становить від декількох міліметрів до діаметра клубової кишки [2].

У більшості випадків ДМ безсимптомний і виявляють випадково під час операційних втручань на органах черевної порожнини. Як супутню патологію його виявляють в 0,1-0,3 \% випадків. Ймовірність клінічних проявів ДМ становить 4,2 \% та значно знижується з віком. Ускладнення ДМ становлять від 25 до 40 \% від загальної кількості випадків цієї патології [3].

Симптоми ДМ завжди є ознаками його ускладнень. Найчастішими ускладненнями є кровотеча (40 \%), кишкова непрохідність (30 \%), дивертикуліт (20 \%) та перфорація дивертикулу (10 \%) [4].

Кишкова непрохідність за частотою посідає друге місце серед ускладнень ДМ. Розглядають такі механізми розвитку кишкової непрохідності внаслідок ДМ: 1) заворот тонкої кишки навколо фіброзного тяжу, що з'єдную дивертикул та пупок; 2) інвагінація диверткула в просвіт КK; 3) грижа Літтре з защемленням ДМ; 4) вузлоутворення КК з ДМ; 5) защемлення тонкої кишки в мезодивертикулярній зв'язці [5].

3 метою видалення ДМ виконують резекцію KK із формуванням анастомозу кінець-в-кінець, клиноподібну резекцію КK, сегментарну резекцію КK, косопоперечну дивертикулектомію, дивертикулектомію кисетним методом, субсерозну резекцію ДМ. Пропонують інвагінаційний метод - шляхом інвагінації ДМ у просвіт кишки. Дані операційні втручання можна виконувати як відкритим, так і лапароскопічним методом [6].
Опис клінічного випадку. Хворий I., 58 років, госпіталізований у КМКЛ № 6 бригадою реанімобіля 05.02.19 р. у тяжкому стані; переведений з однієї з обласних лікарень (де хворий перебував на стаціонарному лікуванні у відділенні реанімації та інтенсивної терапії (ВРIT) з 28.01.19 по 05.02.19 з діагнозом гострий набряковий панкреатит, тяжкий перебіг, двобічний гідроторакс.

3 анамнезу: захворів 28.01.19 р., коли з'явився біль у нижніх відділах живота, нудота, сухість у роті, загальна слабкість. Хворий був госпіталізований в хірургічне відділення однієї з обласних лікарень 3 діагнозом гострий панкреатит, тяжкий перебіг, на основі даних заключення КТ та УЗД органів черевної порожнини, де спостерігали збільшення розмірів підшлункової залози та нерівність її контура.

Хворому проводили інфузійну, протизапальну, антибактеріальну, антисекреторну терапію. Хворомy 30.01.19 р. виконано катетеризацію Tr. Caeliacus 3 метою внутрішньовенного введення антибіотиків. 30.01.19 р. проведено 4 сеанси гемофільтрації. 01.02.19 р. виконано встановлення перидурального катетера для знеболення. В зв'язку з наявністю рідини в правій плевральній порожнині 02.02.19 р. виконано пункцію правої плевральної порожнини, аспіровано 200 мл прозорої рідини. На фоні проведеного лікування стан хворого залишався тяжкий, з негативною динамікою, тому за наполяганням рідних хворого перевели в КМКЛ № 6.

При госпіталізації в КМКЛ № 6 скарги на значне здуття живота, біль у животі без чіткої локалізації, нудоту, сухість у роті, задишку, відсутність випорожнення і відсутність відходження газів. Враховуючи тяжкість стану хворого відразу госпіталізовали у ВРІТ для подальшого обстеження та вибору тактики лікування.

Хворого обстежили. Загальний аналіз крові: гемоглобін - $10^{9}$ г/л, еритроцити - 3,88х1012/л, лейкоцити - 7,2x10\%/л. Глюкоза крові 5,8 ммоль/л. Загальний аналіз сечі: кількість 40 мл, колір світло-солом'яний, слабомутна, білок: 0,033 г/л, 
епітеліальні клітини - поодинокі, лейкоцити - 1-2 у п. 3., еритроцити - 2-3 у п. з., біохімічне дослідження крові: загальний білок 49,2 г/л; сечовина 7,5 ммоль/л, креатинін - 0,115 моль/л, білірубін загальний - 17,4 мкмоль/л, альфа-амілаза - 58,4 ОД/л, АЛТ - 49,2 ммоль/л, АСТ - 31,2 ммоль/л. ПТІ - 68 \%. Група крові A(II) друга, $\mathrm{Rh}(+)$ поз. Електроліти крові: калій (сировотка) - 4,49 ммоль/л, кальцій іонізований - 1,03 ммоль/л, натрій (сировотка) - 130 ммоль/л, хлор (сировотка) - 101,17 ммоль/л. Прокальцитонін - 0,08 нг/мл (норма - менше 0,1). С-реактивний білок (сировотка) - 28,5 мг/л. За даними рентгенографії органів черевної порожнини - чисельні горизонтальні рівні рідини, ознаки тонкокишкової непрохідності. За даними УЗД органів черевної порожнини та плевральних порожнин - підшлункова залоза розмірами 15:14:16 мм. Петлі кишечника розширені до 37 мм, без перистальтики. В правій плевральній порожнині 1100 мл вільної рідини. В лівій плевральній порожнині 680 мл вільної рідини. КТ ОЧП з в/в контрастуванням від 06.02.19. - КТ-ознаки тонкокишкової непрохідності. Мінімальний асцит. Двобічний гідроторакс. Конкременти лівої нирки. Кісти лівої нирки (Basniak I). ЕКГ: ритм синусовий, регулярний, метаболічні зміни міокарда.

05.02.19 р. хворому виконано пункцію правої плевральної порожнини під ультрозвуковим контролем - отримано 800 мл прозорої рідини.

У зв'язку з наявністю ознак гострої кишкової непрохідності хворому після проведення передопераційної підготовки виконано операційне втручання.

06.02.19 р. під загальним знеболенням в об’ємі виконано верхньо-серединну лапаротомію, ревізію. При ревізії петлі тонкої кишки дилатовані до 60 мм. На відстані 150 мм від ілеоцекального кута виявлено інфільтрат, що складається з петлі тонкої кишки, пасма великого сальника з утворенням “вікна”,

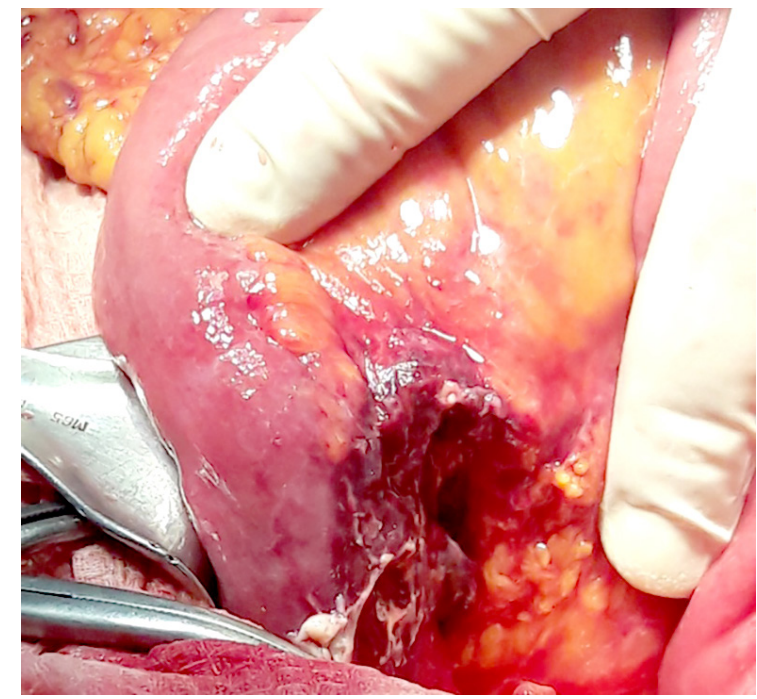

Рис. 1. Порожнина абсцесу. в якому фіксована ділянка здухвинної кишки. Виконано роз'єднання інфільтрату, вивільнено петлю тонкої кишки з “вікна”, розкрито міжпетельний абсцес об'ємом до 10 мл, стінками якого є брижа тонкої кишки, пасмо великого сальника та стінка тонкої кишки з ділянкою, що містить гангренозно змінений ДМ з перфорацією в ділянці його верхівки (рис. 1). Виконано видалення ДМ, з зануренням його культі кисетним методом (рис. 2). Виконана назогастроінтестинальна інтубація з декомпресією та лаважем тонкої кишки. Санація, дренування черевної порожнини, порожнини міжпетельного абсцесу.

Після операції встановлено діагноз дивертикулу Меккеля, ускладнений некрозом дивертикулу та перфорацією, міжпетельним абсцесом, тонкокишковою декомпенсованою непрохідністю, загальний серозний перитоніт, полісерозит.

Післяопераційний період перебігав тяжко. Хворий після операції знаходився у ВРІТ, де проводилось комплексне лікування в об'ємі: тієнам 1 гр х 4 р/д в/в, альбумін $20 \%$ 100,0 в/в, глюкоза $5 \%$ 400,0, ізосол 500,0 в/в, реосорбілакт 400,0 в/в, фленокс 0,4 мл п/ш, інфулган 1000 мг в/в, нексіум 40 мг в/в, лонгокаїн 0,25 \% в епідуральний катетер 4,0 х 3-4 p/ добу, осетрон 8 мг в/в, ксефокам 8 мг х 2-3 р/д, латрен 200,0 в/в, L-лізин 5,0 в/в, нутрилон 50 мл, еспумізан, виконували очисні клізми, перев'язки з антисептиками.

На фоні проведеного лікування стан хворого в динаміці покращувався. 11.02 .19 р. хворого перевели в 1-ше хірургічне відділення для подальшого лікування.

У 1-му хірургічному відділенні хворий отримував лікування: тієнам 1 гр х 4 р/д в/в, альбумін 20 \% 100,0 в/в, стерофундін 500,0 в/в, реосорбілакт 200,0 в/в, фленокс 0,2 мл п/ш, інфулган 1000 мг в/в, нексіум 40 мг в/в, лонгокаїн 0,25 \% в епідуральний

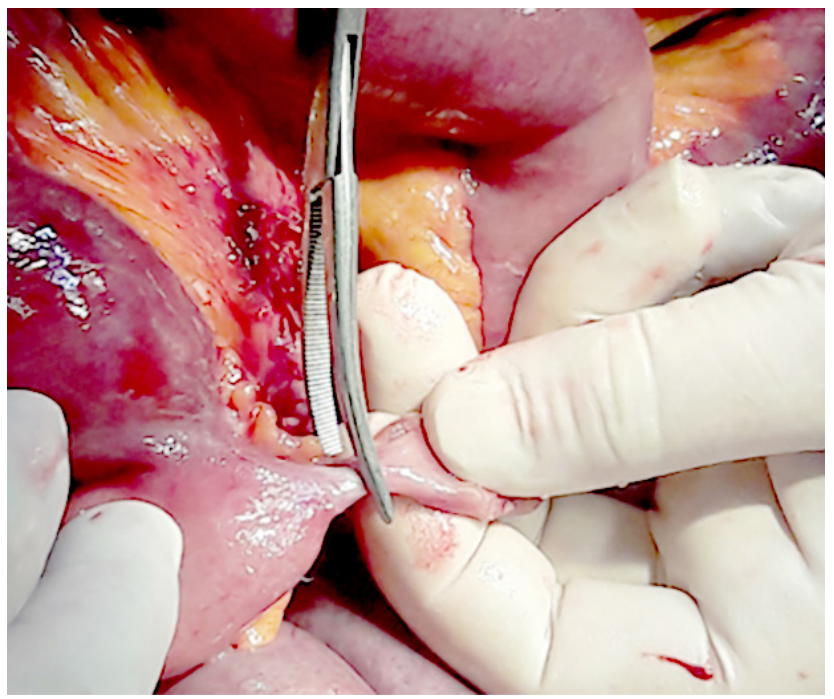

Рис. 2. Видалення дивертикулу Меккеля. 
катетер 4,0 х 3-4 р/добу, осетрон 8 мг в/в, флуконазол 100,0 в/в, мільгамма 5,0 в/в, кейвер 2,0 в/м, лактіале 1 капс. х 3 р/д, спазмалгон 2,0 в/м. Після проведеного лікування стан хворого покращився. Інтубаційний зонд видалено 12.02 .19 р., дренаж із черевної порожнини видалено 14.02.19 р.

Післяопераційна рана загоїлась первинним натягом, шви знято. За даними контрольного УЗД органів черевної порожнини та плевральних порожнин в правій плевральній порожнині до 70 мл рідини, в лі-

\section{СПИСОК ЛІТЕРАТУРИ}

1. Mattei P. Fundamentals of pediatric surgery / P. Mattei. - NY: Springer Science+Business Media, LLC. - 2011. - P. 206-208.

2. Дивертикул Меккеля у дітей / А. А. Данилов, А. М. Урін, В. Ф. Рибальченко [та ін.] // Хірургія дитячого віку. - 2006. - № 3(12). - С. 56-60.

3. Гриценко Є. М. Дивертикул Меккеля та його ускладнення в хірургії дитячого віку / Є. М. Гриценко, М. І. Гриценко // Хірургія дитячого віку. - 2006. - № 2(11). - С. 60-64.

4. When to resect and when not to resect an asymptomatic

\section{REFERENCES}

1. Mattei, P. (2011). Fundamentals of pediatric surgery. NY: Springer Science+Business Media, LLC.

2. Danilov, A.A., Urin, A.M., \& Rybalchenko, V.F. (2006). Dyvertykul Mekkelia u ditei [Meckel's diverticulum in children]. Khirurhiia dytiachoho viku - Surgery of Childhood, 3 (12), 56-60 [in Ukrainian].

3. Hrytsenko Ye.M., \& Hrytsenko M.I. (2006). Dyvertykul Mekkelia ta yoho uskladnennia v khirurhii dytiachoho viku [Meckel's diverticulum and in children and it's complications]. Khirurhiia dytiachoho viku - Surgery of Childhood, 2 (11), 60-64 [in Ukrainian]. вій плевральній порожнині вільна рідина відсутня. В черевній порожнині вільна рідина відсутня.

Хворого в задовільному стані виписали для подальшого амбулаторного лікування під наглядом хірурга поліклініки. Надано рекомендації.

Дивертикул Меккеля зустрічається в 0,1-0,3 \% випадках у хірургічній практиці. Об’єктивним методом діагностики дувертикула Меккеля є ультразвукове дослідження та комп’ютерна томографія органів черевної порожнини.

Meckel's diverticulum: an ongoing challenge / A. Onen, M. Kemal, H. Ozturk [et al.] // Pediatr. Surg. Int. - 2003. Vol. 19, No. 1. - P. 57-61.

5. Sharma R. K. Emergency surgery for Meckel's diverticulum / R. K. Sharma, V. K. Jain [et al.] // World Journal of Emergency Surgery. -2008. - Vol. 27, No. 3. - P. 1-8.

6. Видеолапароскопические операции при патологии дивертикула Меккеля у детей / А. Ф. Дронов, И. В. Поддубный, В. И. Котлобовский [и др.] // Хирургия. - 2002. - № 10. - С. 39-42.

4. Onen, A., Kemal, M., \& Ozturk, H. (2003). When to resect and when not to resect an asymptomatic Meckel's diverticulum: an ongoing challenge. Pediatr. Surg. Int., 19 (1), 57-61.

5. Sharma, R.K., \& Jain, V.K. (2008). Emergency surgery for Meckel's diverticulum. World Journal of Emergency Surgery, 27 (3), 1-8.

6. Dronov, A.F., Poddubnyy, I.V., Kotlobovskiy, V.I. (2002). Videolaparoskopicheskie operatsii pri patologii divertikula Mekkelya u detey [Laparoscopic surgeries in case of Meckel's diverticulum in children]. Khirurgiya - Surgery, 10, 39-42 [in Russian].

Отримано 26.04.2019

V. V. KRYZHEVSKYI, M. I. ZNAIEVSKYI, O. O. BILYAYEVA, A. P. KOLOMOITSEV

Kyiv City Clinical Hospital No. 6

\section{DIAGNOSIS AND SURGICAL TREATMENT OF MEGKEL'S DIVERTICULUM: GLINICAL CASE REPORT}

The article provides a clinical case exemplifying difficulties in Meckel's diverticulum diagnosis, complicated by gangrene and perforation, interintestinal abscess, intestinal obstruction and general serous peritonitis.

Key words: Meckel’s diverticulum; acute pancreatitis; diagnosis; treatment.

В. В. КРИЖЕВСКИЙ, Н. И. ЗНАЕВСКИЙ, О. А. БИЛЯЕВА, А. П. КОЛОМОЙЦЕВ

Киевская городская клиническая больница № 6

\section{КЛИНИЧЕСКИЙ С.ЛУЧАЙ С.ЛОННСТИ ДИАГНОСТИКИ И ХИРУРГИЧЕСКОГО ЛЕЧЕНИЯ ДИВЕРТИКУЛА МЕККЕЛЯ}

\footnotetext{
В статье представлен случай трудности диагностики дивертикула Меккеля, осложненного некрозом и перфорацией дивертикула, междупетельным абсцессом, тонкокишечной декомпенсированной непроходимостью, общим серозным перитонитом.

Ключевые слова: дивертикул Меккеля; острый панкреатит; диагностика; лечение.
} 